\title{
The Reaction of Fiscal Policy to the Crisis in Italy and Germany: Are they really polar Cases in the European Context?
}

\author{
Britta Hamburg, Sandro Momigliano, Bernhard Manzke y Stefano Siviero
}

Revista de Economía y Estadística, Cuarta Época, Vol. 48, No. 2(2010), pp. 103-133.

http://revistas.unc.edu.ar/index.php/REyE/article/view/4108

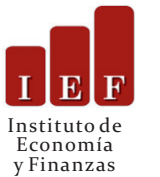

La Revista de Economía y Estadística, se edita desde el año 1939. Es una publicación semestral del Instituto de Economía y Finanzas (IEF), Facultad de Ciencias Económicas, Universidad Nacional de Córdoba, Av. Valparaíso s/n, Ciudad Universitaria. X5000HRV, Córdoba, Argentina.

Teléfono: 00 - 54 - 351 - 4437300 interno 253.

Contacto: reveco estad@eco.unc.edu.ar

y Finanzas

Dirección web http://revistas.unc.edu.ar/index.php/REyE/index

Cómo citar este documento:

Hamburg, B., Momigliano S., Manzke B. y Siviero S. (2010). The Reaction of Fiscal Policy to the Crisis in Italy and Germany: Are they really polar Cases in the European Context?. Revista de Economía $y$

Estadística, Cuarta Época, Vol. 48, No. 2, pp. 103-133.

Disponible en: <http://revistas.unc.edu.ar/index.php/REyE/article/view/4108>

El Portal de Revistas de la Universidad Nacional de Córdoba es un espacio destinado a la difusión de las investigaciones realizadas por los miembros de la Universidad y a los contenidos académicos y culturales desarrollados en las revistas electrónicas de la Universidad Nacional de Córdoba. Considerando que la Ciencia es un recurso público, es que la Universidad ofrece a toda la comunidad, el acceso libre de su producción científica, académica y cultural.

http://revistas.unc.edu.ar/index.php/index

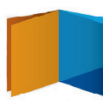




\title{
The Reaction of Fiscal Policy to the Crisis in Italy and Germany: Are they really polar Cases in the European Context?
}

\author{
Britta Hamburg \\ Bundesbank, \\ britta.hamburg@bundesbank.de
}

Sandro Momigliano

Banca d'Italia

sandro.momigliano@bancaditalia.it

Bernhard Manzke

Bundesbank

bernhard.manzke@bundesbank.de

\section{Stefano Siviero}

Banca d'Italia

stefano.siviero@bancaditalia.it

\begin{abstract}
The deep recession which hit the world economy towards the end of 2008 induced massive, internationally-coordinated policy responses, both monetary and fiscal. In this paper we examine public finance developments in Germany and Italy in 2009. We fi nd that the larger stimulus measures adopted in Germany mostly compensated a more favourable underlying trend; overall, the cyclically-adjusted primary balances worsened by a similar extent in the two countries. We further estimate the automatic stabilisers to have had an impact on the defi cit of similar magnitude in Germany and Italy. We then assess, on the basis of counterfactual simulations, to which extent discretionary measures and automatic stabilizers were able to mitigate the downturn in the two countries. Our results show that the public sector contrasted the fall in real GDP in 2009 by more than 2 percentage points in Germany and by 1 per cent in Italy. The difference in the stabilizing effect of the two public
\end{abstract}


sectors reflects not only the different size of the stimulus measures, but also the higher fiscal multipliers associated with Germany.

Keywords: Discretionary Fiscal Policy; Automatic Stabilizers Germany; Italy. JEL Classification: E62; H30.

\section{Resumen}

La profunda depresión que golpeó a la economía mundial hacia finales del 2008 indujo numerosas respuestas de politica coordinadas a nivel global, tanto monetarias como fiscales. En este trabajo examinamos las políticas relativas a las finanzas públicas por parte de Alemania e Italia durante el año 2009. Encontramos que las medidas de estímulo más importantes adoptadas en Alemania compensaron, en mayor parte, una tendencia subyacente más favorable; en general, los saldos ajustados en función del ciclo primario se agravaron en similar magnitud en los dos países. Estimamos además que los estabilizadores automáticos han tenido un impacto sobre el déficit de magnitud similar tanto en Alemania como en Italia. A continuación, en base a simulaciones contra-fácticas, analizamos en qué grado las medidas discrecionales y los estabilizadores automáticos fueron capaces de mitigar la crisis en los dos países. Los resultados muestran que el sector público contrarrestó la caída del PIB real en 2009 en más de 2 puntos porcentuales en Alemania y en un 1 por ciento en Italia. La diferencia en el efecto estabilizador de los dos sectores públicos refleja no sólo la diferente magnitud de las medidas de estímulo, sino también la presencia de un multiplicador fiscal más elevado en Alemania.

Palabras clave: Política Fiscal Discrecional, Estabilizadores Automáticos, Alemania, Italia.

Clasificación JEL: E62; H30.

\section{INTRODUCTION}

At the end of 2008, when the worldwide recession began, public finances in Italy and in Germany were strikingly different. The level of public debt was close to 106 per cent of GDP in Italy and as much as 40 percentage points lower in Germany. Furthermore, the former country posted a deficit already close to the Maastricht threshold (2.7 per cent of GDP), while Germany's budget was exactly balanced. ${ }^{1}$ The main public finance aggregates showed relatively minor differences, with the revenue ratio and

1. The difference in the overall balance was due to higher interest payments in Italy, while the level of the primary balance was roughly the same in the two countries. 
the primary expenditure ratio in Italy being higher by almost 2 percentage points. Section 2 below examines to what extent the differences in fiscal positions in 2008 depended on the policies implemented by Germany and Italy since 1997 - the year relevant for qualification to participate in the Monetary Union.

Given their fiscal conditions in 2008, it is not surprising that the size of the discretionary measures adopted by the two countries facing the looming recession were at the extremes of the range spanned by the reactions of all European governments. ${ }^{2}$ The gap in the debt levels took particular relevance in the context of the widening of the spreads between government bonds in the last months of 2008, which warned that sizeable expansionary fiscal action in Italy would result in higher financing costs. For Germany, on the contrary, additional public borrowing was not perceived to increase the pressure on interest rates.

The timing, magnitude and composition of the stimulus actions adopted in Germany and Italy for 2009 and 2010 are examined in Section 3. The comparative analysis for 2009 shows, inter alia, that the larger deficitincreasing impact of the measures adopted in Germany mostly compensated a more favourable underlying development in the balance in that country. Compared to Germany, the Italian fiscal actions intervened more on the composition of the budget in order to stimulate the economy, while limiting the short-term effects on the deficit. The budgetary impact of automatic stabilizers is found to be largely similar. Going forward, the picture for 2010 seems more clear cut. While the deficit ratio in Italy is expected to improve marginally, for Germany it is projected to rise by $3 / 4$ percentage points, reflecting further sizeable stimulus measures which are only to a limited extend offset by a positive impact from the cycle.

In Section 4 the effects of the stimulus measures and the automatic stabilizers on the Italian and German economies in 2009 are assessed on the basis of counterfactual simulations of the econometric models used, respectively, in the Bank of Italy and in the Deutsche Bundesbank. We find that, overall, general government developments limited the fall in real GDP in 2009 by more than 2 percentage points in Germany and by 1 point in Italy. This gap reflects both the different size of the stimulus measures in the two countries and the higher fiscal multipliers estimated for Germany.

Section 5 concludes.

2. European Commission (2009), Table I.1.1, p. 14. 


\section{FISCAL POLICIES BEFORE THE CRISIS: FROM 1998 TO 2008}

Between 1997 and 2008, the general government deficit in Germany and Italy followed separate paths: while it turned from a deficit of 2.6 per cent of GDP into a marginal surplus in the former country, it remained stable in the latter, at 2.7 per cent of GDP. In the same period, the Italian public debt declined by 11.7 percentage points, to 106.3 per cent of GDP, while that of Germany rose by 6.6 percentage points, to 66.3 per cent (Figure 1).

In this period, German and Italian fiscal policies did not fully comply with the European fiscal criteria. The net borrowing in both countries exceeded for four years in a row the 3 per cent of GDP limit set by the Treaty on the Functioning of the European Union (TFEU). The excessive deficits occurred at the beginning of the decade, in the context of a recession which can be deemed at most mild - particularly from today's standpoint. As for the limit indicated in the Treaty for public debts (60 per cent of GDP), after 2002 Germany's debt consistently exceeded the threshold, with a clear upward trend. In the case of Italy, given the very high starting condition, the modest reduction in the debt ratio did not meet the Treaty provision that it be "sufficiently diminishing and approaching the reference value at a satisfactory pace". Moreover, approximately two thirds of the reduction were due to extraordinary operations (debt restructuring and sale of assets) which left the public sector net wealth unchanged (Momigliano and Rizza, 2007). Finally, precisely in view of its high debt level, Italy had vowed (at the ECOFIN Council held in York in March 1998; Corriere della Sera, 1998) to achieve a rapid convergence towards the Treaty benchmark debt level, by maintaining a primary surplus equal or above 5 per cent of GDP. Had this commitment been met, ceteris paribus, in 2008 the debt level would have been close to 80 per cent of GDP.

Developments in primary balances are reported in Figure 2 (left panel; data adjusted for cyclical effects ${ }^{3},{ }^{4}$ and temporary government measures are shown in the right panel).

Excluding interest payments from the balance (see Figure 2, left) does not affect the analysis for Germany, as this budgetary item remains largely

3. Data were adjusted using the methodology developed within the European System of Central Banks (see Bouthevillain et al., 2001; Kremer et al., 2006a, and, for applications of the method in Germany and Italy, Kremer and Wendorff, 2004; Kremer et al., 2006b; and Marino et al., 2008a and 2008b).

4. These effects are usually the most important transitory factors, but we are still far from capturing the influence of all temporary factors on public finances. Other temporary factors with an impact on revenue include fluctuations in interest rates and in prices of real estate, stocks and oil. 
unchanged in the period. For Italy, instead, the examination of the primary balance unveils a rapid and almost continuous deterioration between 1997 - when it stood at 6.6 per cent of GDP - and 2005, when it was virtually nil. ${ }^{5}$ After 1997, Italian public finances progressively benefited from the fall in rates which occurred after joining the Monetary Union. However, interest payments savings did not result in an improvement in the balance; rather, they were largely used to reverse the increases in revenue and cuts in health and capital expenditure which had taken place in the fiscal adjustment of the years 1992-97 (Degni et al., 2001; Balassone et al., 2002, Marino et al., 2008a).

Figure 1

\section{General Government Net Borrowing and Public Debt (percent of GDP)}

\section{General Government Balance}

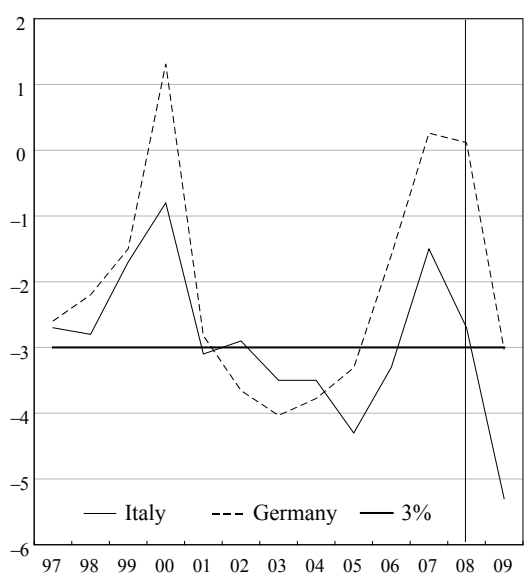

Public Debt

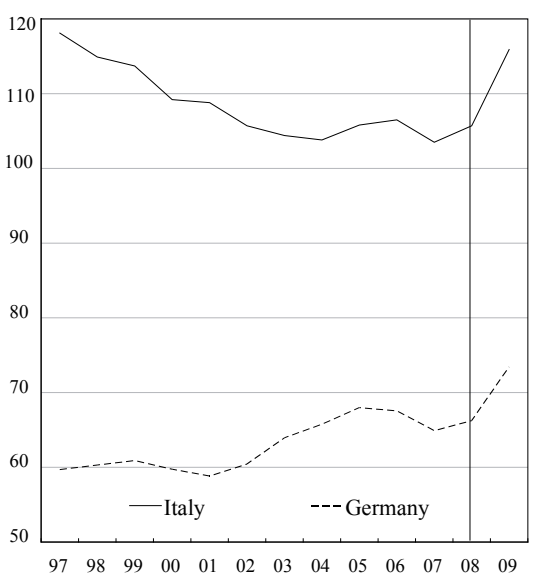

Note: The balances and the dynamics of the debt in 2000 were influenced by the extraordinary proceeds from the sale of UMTS licences (2.4 and 1.2 per cent of GDP, respectively, in Germany and Italy).

5. In this paper we consider the budget balance definition which is relevant for the excessive deficit procedure, i.e. the general government balance including the effects of swaps and forward rate agreements. Furthermore, for an homogeneous comparison, the general government revenue and expenditure are defined according to the criterion adopted by the EU (Regulation EC/1500/2000, relevant for the updates of the stability programme), which differs from the "traditional criterion" used in the national accounts published by the Italian National Institute of Statistics (ISTAT). 


\section{Figure 2}

\section{General Government Primary Surplus}

(unadjusted and structural)

General Government Primary Surplus (percent of GDP)

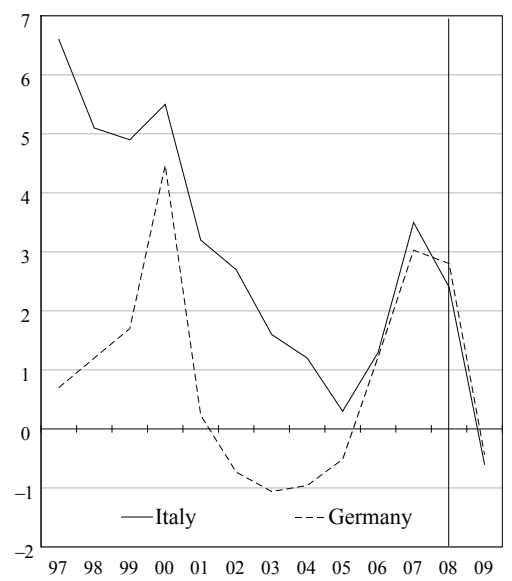

Structural Primary Surplus (percent of trend GDP)

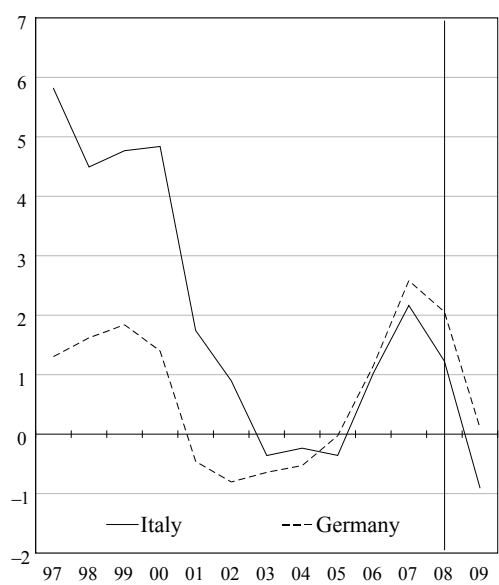

The path of the structural primary balance (i.e. adjusted for the effects of the cycle and temporary measures) in the two countries broadly confirms the analysis above. However, a few remarkable differences are apparent. First, the worsening trend in Italy ends two years earlier than shown by the unadjusted primary balance, approximately in 2003, when the gap in the structural primary balance between the two countries also closes. Second, Italy and Germany appear to have followed largely similar fiscal policies in the following years, as their structural primary balances move closely together. As will be seen when we turn to 2009, the fiscal stance of the two countries remained similar last year too.

In Figure 3 we show the development of revenue and primary expenditure in the two countries, adjusted for the effects of the economic cycle and temporary government measures. We find a striking difference between the two countries in the dynamics of the structural primary expenditures (as a ratio to trend GDP): in 1997 this aggregate was 3.5 percentage points higher in Germany than in Italy, while 11 years later it was lower by over 1.5 percentage points. This reversal is due for $3 / 4$ to the increase in the Italian expenditure ratio and for $1 / 4$ to the decline in that of Germany. Large differences can be found for social expenditures (which increased by 2 percentage points of trend GDP in Italy, while they declined by 0.3 in Germany) and public wages and salaries (which in Italy 
increased by 0.2 percentage points while in Germany they declined by $1 \mathrm{pp}){ }^{6}$ In Marino et al. (2008b), the increase in structural Italian expenditures between 1997 and 2007 is largely attributed to the strong dynamics of health and capital expenditures. In Germany, the decline in the ratio between social payments and trend GDP started in 2003, following comprehensive reforms of the welfare system. The dynamics of German public wages and salaries remained subdued over the whole period, reflecting the decline in the number of government employees and the moderation in wage agreements (with the agreements being systematically lower than in the private sector). As for the structural revenue ratio, it dropped by approximately 2 percentage points in both countries, with the Italian ratio remaining higher than the German one by about 1 percentage point. For both countries the increase in 2006-07 is driven by unexpected revenue windfalls, largely concentrated in profit-related taxes, and legislative measures.

Summing up, public sector developments in Germany and Italy between 1998 and 2008 show both similarities and differences.

First, both countries clearly failed to fully comply with the European fiscal criteria, for both deficit and debt. However, in the later years overall and primary balances improved more in Germany, reflecting to a large extent the

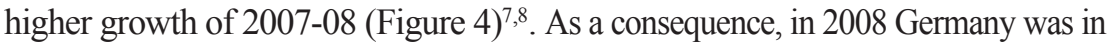
a far better position to cope with the recession. Nevertheless, even the German fiscal margin at end-2008 was not fully adequate, given the depth of the 2009 recession.

Second, in terms of primary balance and expenditure - two key indicators for assessing the soundness of public finance - the performance of the two countries was strikingly different. While Italy completely dissipated the Maastricht dividend of lower interest rates on higher primary expenditures (and, to a lesser extent, lower revenues), Germany achieved a substantial reduction in primary expenditure, which resulted in an improvement of the primary balance in spite of falling revenues. ${ }^{9}$

6. In nominal terms, in the period 1998-2008 the average growth of unadjusted primary expenditure in Italy is 4.8 per cent, against 1.7 per cent in Germany. The gap shrinks only marginally in the last years: in the period 2004-08 the average growth declines in both countries to, respectively, 3.5 per cent and 0.8 per cent.

7. Between 1997 and 2006 the cumulated growth of the two countries is almost identical, while in the following two years in Italy it is a mere 0.2 per cent, while in Germany it amounts to 3.8 per cent.

8. The different fiscal position of the two countries in 2008 was also influenced by the German better structural performance in 2005 .

9. The decline of the revenue ratio seems to have been largely caused by a negative decoupling of growth of important macroeconomic assessment bases from GDP growth whereas legislative changes are positive and a substantial fiscal drag has accumulated in the period. 
The structural deterioration of Italian primary balance essentially occurred in the years 1998-2003. In the following 5 years the levels of the structural primary balances in the two countries moved together, indicating that Italy and Germany adopted broadly similar policies.

Figure 3

Structural Revenue and Primary Expenditure (percent of trend GDP)

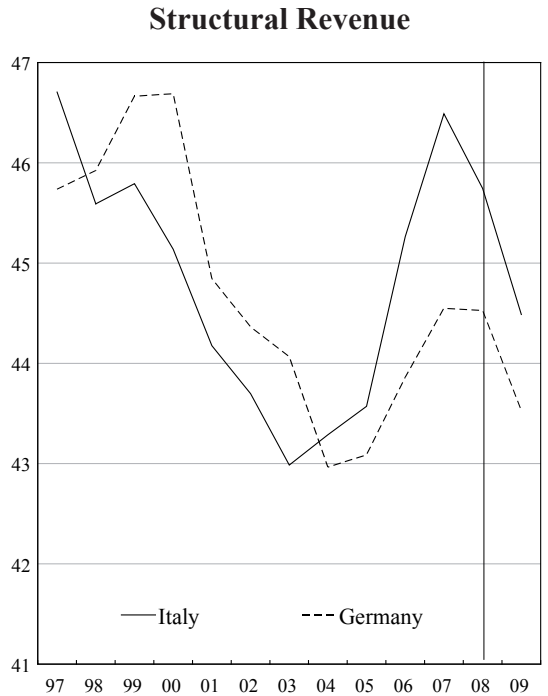

Structural Primary Expenditure

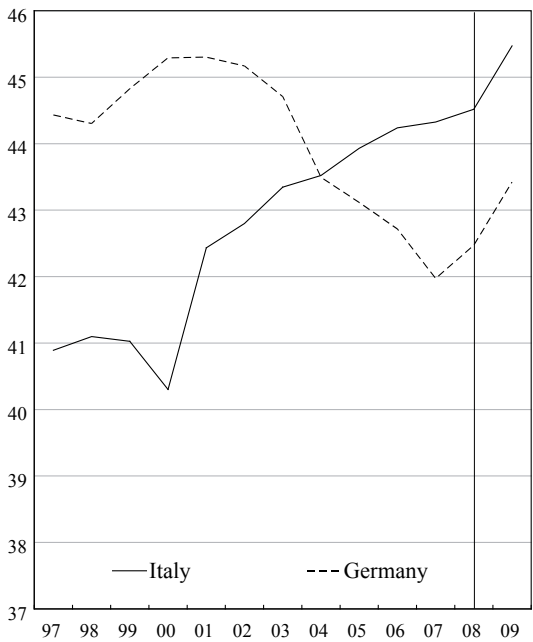

Figure 4

GDP (index: 1997=1)

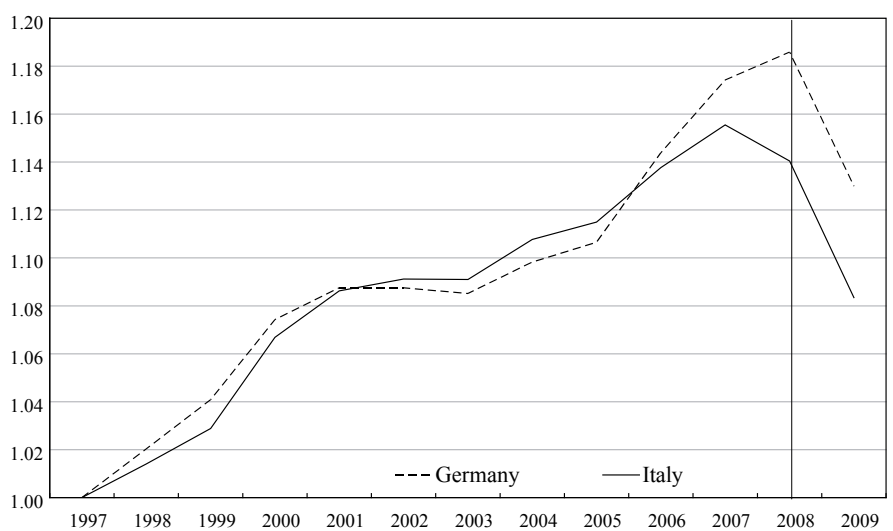




\section{THE FISCAL RESPONSE TO THE CRISIS}

The first clear fiscal reaction to the crisis took place in November 2008 in both Italy and Germany, after the sudden, dramatic escalation of the financial market turmoil, with both countries issuing an emergency stimulus package. ${ }^{10}$ In the previous months, a number of fiscal measures had been adopted which were unrelated to the looming crisis. In August, Italy had approved a deficit-reducing three-year budget, with an impact on net borrowing estimated at 0.6 per cent of GDP in 2009 (1.0 per cent in 2010). ${ }^{11}$ In October, Germany had introduced a number of measures with a combined deficit-increasing effect amounting to 0.3 per cent of GDP for 2009 ( 0.6 per cent in 2010). ${ }^{12}$ As shown in Figure 5, when these decisions were taken, GDP growth projections, though not particularly favourable, were still positive for both countries.

The measures taken by Germany and Italy before November went into the direction of aligning the fiscal stance for 2009 in the two countries, offsetting the divergent trend of their budget balances which would have occurred in a no-policy-change scenario. Early in November, the European Commission's assessment of macroeconomic and budgetary developments for 2009 was almost identical for the two countries: in both Germany and Italy real GDP was expected to stagnate and the deficit was envisaged to worsen by 0.2 percentage points of output (European Commission, 2008). Ex post data for 2009 seem to show that the pre-November policies were not able to fully close the divergent trend of the budget balances in the two countries, as explained further on.

10. Prior to that, both governments (and particularly the German one) had taken action, together with monetary policy authorities, to contribute to avert the collapse of their respective financial systems.

11. The three-year budget was basically confirmed in the Finance Bill for 2009, presented to the Parliament at the end of September.

12. Indeed, the enlarged deductability of insurance contributions as of 2010, which of all these measures has the largest deficit impact, followed from an earlier ruling of the constitutional court. 


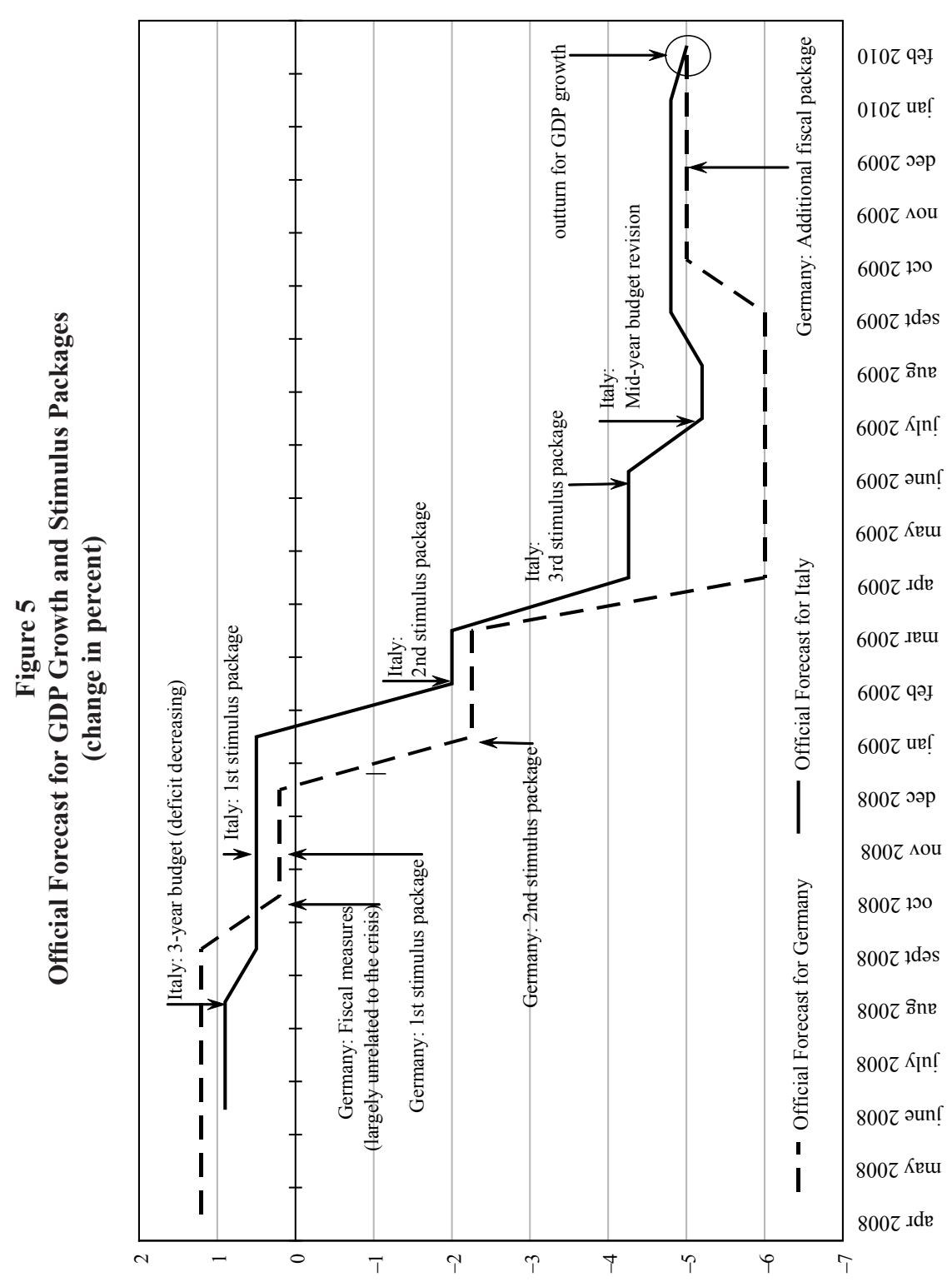


The Italian stimulus package introduced in November included transfers to low-income households and, on a smaller scale, relief measures for enterprises. According to government estimates, those measures were fully financed by revenue increases, mainly by means of the introduction of a voluntary substitute tax on asset re-evaluations and, to a lesser extent, by means of expenditure cuts. ${ }^{13}$ The German stimulus package, by contrast, was estimated to increase the deficit by 0.2 per cent of GDP in 2009 and 0.3 per cent in $2010 .{ }^{14}$ It consisted mainly of additional public investment, a temporary reintroduction of declining-balance depreciation for machinery and equipment, and an extension of tax deductions allowed for handicraft services.

In December 2008 the European Council called on member states to coordinate the fiscal response to the crisis by implementing a European Economic Recovery Plan which recommended a budgetary stimulus of 1.5 per cent of GDP cumulatively for 2009 and 2010 (1.2 per cent of GDP by member states and 0.3 per cent at the EU level). The stimulus was required to be TTT (temporary, timely and targeted). Moreover, countries with more fiscal room for manoeuvre were asked to provide a larger fiscal stimulus than countries with a less favourable starting position. The decision of the European Council called on Germany - until then reluctant to expand its budget - to do more to sustain the economy, while giving political support to the prudent attitude adopted by the Italian Government.

Around the turn of the year it became increasingly clear that not only countries with bubbles in the housing markets and low competitiveness would be severely affected by the global downturn, but also - or even especially - open economies with a large share of investment and durable consumption products in their exports. The latter description fits perfectly Germany and, to a lesser extent, Italy as well; the strong economic ties between the two countries made it also likely that their destinies in the upcoming recession be closely linked.

The rapid deterioration of macroeconomic prospects (Figure 5) induced both countries to implement a second stimulus package shortly after the first. This time Germany reacted first, in January 2009, and with a far larger intervention, whose estimated impact on the 2009 deficit amounted to 0.7 per cent of GDP (1.1 per cent in 2010). The main measure was an increase in public infrastructure investments; the package also included income tax reductions and

13. As the revenue from the substitute tax was higher than expected, overall the package is likely to have reduced the deficit ex post.

14. The figures on the fiscal impact of the various measures reflect government estimates and our own assessment. 
a reduction of the contribution rate to the statutory health insurance. Various measures to dampen the labour market effects of the crisis were put in place, most importantly additional support for short-time work. Transfer payments to households were increased, mainly through a one-off child bonus to be paid in the Spring. The provisions included a temporary car scrapping premium paid to households (extended in April). The second Italian fiscal package was passed in February 2009; it too included a similar car scrapping incentive, financed partly by closing some tax loopholes and partly by the higher tax revenue expected from the increase in car purchases induced by the measure.

The synchronization of the fiscal reaction in the two countries ends with the second stimulus package. In June, amid signs of a worldwide easing of the recession but in the presence of a steady and worrisome deterioration of the labour market, the Italian government approved an additional anti-crisis decree - designed once again to be neutral on the budget balance - which included provisions aimed at strengthening the social safety net and, most notably, introducing large tax incentives for purchases of machinery in the following 12 months. Furthermore, the mid-year budget revision in July included temporary boosts to intermediate consumption and public investment. These measures entailed a 0.3 percentage points of GDP impact on the public balance for 2009; this being the only deficit-increasing package to be approved throughout the crisis. The budget for 2010, passed by the Parliament at the end of December 2009, ${ }^{15}$ once again included expenditure increases (amounting to 0.2 per cent of GDP), financed by an extraordinary tax (the so-called "tax shield"), ${ }^{16}$ with an estimated zero effect on the balance.

As for Germany, only in December of 2009 did the newly-elected government pass an additional fiscal package with the objective of providing a further stimulus and fostering long-run growth. ${ }^{17}$ The measures included a further increase in child benefits, reductions of enterprise and inheritance taxes and a lower VAT rate for accommodation services, which accompanied a temporary grant to the health fund. In total, the impact of the package on the budget balance in 2010 was estimated at 0.4 per cent of GDP.

15. The budget was partly anticipated, as in 2008, by a decree (No. 112) in the Summer.

16. The revenue which in October 2009 was expected to be raised in December from the foreign assets disclosure scheme ( 0.25 per cent of GDP) was shifted from 2009 to 2010 by reducing the size of the advance personal income tax payment due at the end of 2009. Ex post the revenue from the scheme was slightly higher than expected (less than an additional 0.1 per cent of GDP) and the additional receipts improved the balance in 2009.

17. Minor relief measures for enterprises were adopted in July 2009, with an effect on the deficit in 2009 lower than 0.1 per cent of GDP. 
Summing up, if we include all actions taken since the summer of 2008, in Italy discretionary measures improved the budget balance by 0.3 per cent of GDP in 2009 and by approximately 1.0 in 2010 (reflecting the restrictive measures taken before the crisis exploded, only partly offset by deficit-increasing measures issued in late 2009), while in Germany fiscal policies worsened the balance by respectively 1.3 and 2.5 per cent of GDP. ${ }^{18}$

In our analysis we focus on the crisis-motivated discretionary measures taken since November 2008. ${ }^{19,20}$ In our assessment these measures have led to a fiscal loosening far greater in Germany (with an impact on the deficit amounting to 1.1 per cent of GDP in 2009 and about 2 per cent in 2010) than in Italy ( 0.3 and basically zero, respectively, for the two years) ${ }^{21},{ }^{22}$ While official figures for 2009 are available, for 2010 they obviously are not. Our estimates for this year should thus be treated with particular caution; this is one of the reasons why most of our empirical results in Section 4 focus on 2009.

Obvious reasons led Italy to a more prudent behaviour, among which the worse starting position for both deficit and debt. The different ex ante orientation of fiscal policy may also reflect differing real-time expectations concerning the size of the downturn. As shown in Figure 5, in the first months of 2009 the worsening of the outlook was more pronounced in Germany than in Italy. Finally, budgetary rules in Italy do not allow for deficit-increasing packages except in the case of the Finance Bill. Therefore, after the budget for

18. Measures that do not have an (immediate) impact on the general government deficit like guarantees or off-budget measures (especially in the context of support for the financial sector) are not included in this analysis although they might have a significant impact on macroeconomic variables.

19. The reintroduction of the commuters allowance in Germany (which followed a ruling by the Constitutional Court in December 2008) and the actions taken following the earthquake in Abruzzo in April 2009 in Italy are also excluded, by referring to the stated intention of the governments.

20. The reasons for focusing on the measures taken since November 2008 are the following. First, the fiscal packages introduced before were publicly motivated by reasons different from the economic crisis (e.g., consolidation for Italy). Second, these actions were decided when GDP growth projections for both countries were still positive.

21. The estimated effects of the discretionary measures reflect a number of positive and negative adjustments to the original official estimates of the fiscal packages. For Italy, for 2009 and 2010 these adjustments broadly balance out. With regard to 2009, on the one hand, the revenue from the voluntary substitute tax on asset revaluations was higher than originally expected ( 0.4 per cent of GDP, instead of less than 0.2 per cent), likewise the proceeds of the "tax shield" exceeded the resources shifted to 2010 by 0.07 per cent of GDP. On the other hand, a number of financing instruments seem likely to have been less effective than originally expected. For Germany, the additional public investment included in the stimulus programmes is assumed to be implemented with substantial delay compared to the initial government plans.

22. Our assessment is not significantly different from that presented in European Commission (2009), p. 14. The figures provided there do not include more recent measures. 
2009 had been passed in December 2008, the Italian government had little leeway (until the mid-year budget revision) to introduce expansionary measures in response to the deteriorating growth outlook. In contrast, in Germany two supplementary deficit-increasing budgets were adopted in the course of 2009 at the central level; similar actions were taken at the regional level.

Table 1

Fiscal Policy In Italy and Germany in 2009 (change in ratio to GDP in percentage points with respect to 2008) (deficit-increasing: + )

\begin{tabular}{l|cc} 
& Italy & Germany \\
\hline All Measures (percent of GDP) & -0.3 & +1.3 \\
Stimulus Measures (percent of GDP) & +0.3 & +1.1 \\
Automatic Stabilizers & +1.4 & +1.6 \\
Other Changes in Primary Balance & +1.4 & +0.5 \\
Overall Change in Primary Balance & +3.1 & +3.2 \\
\hline
\end{tabular}

By focusing exclusively on discretionary fiscal measures, however, the assessment of the stabilising role of fiscal policy may well be significantly distorted, particularly in the context of cross-country comparisons. ${ }^{23}$

Firstly, macroeconomic fluctuations are dampened by automatic stabilizers. With regard to Italy and Germany in 2009, however, including the impact of the latter (estimated on the basis of the method presented in Bouthevillain et al., 2001) does not fundamentally change the relative ranking of the two countries, as they are of almost equal size in both (Table 1).

Secondly, focusing exclusively on discretionary measures leads to neglecting the fact that differences in the existing legislations may imply divergent trajectories for the budget balance, even if the macroeconomic environment is the same for both countries. Therefore, for example, restrictive discretionary measures in one country may simply compensate for a larger - in relative terms - trend growth of expenditure under existing legislation.

One way to deal with this shortfall is to look at changes in the cyclically-adjusted primary balance (CAPB, i.e., the budget balance net of cyclical effects), as this takes simultaneously into account the effects of discretionary 
measures and of other structural changes. This indicator, commonly used to assess the fiscal stance of one country, also shows an almost equal loosening in the two countries (a worsening of 1.6 per cent and 1.7 per cent respectively in Germany and in Italy).

This finding - which suggests that caution should be exercised when comparing the fiscal policies of the two countries - appears to be attributable, to a large extent, to the relatively strong growth in pension expenditure and larger revenue shortfalls in Italy. It may also be related to the fact that the two governments not only had good reasons to react differently to the crisis, but also that they could reap some short-term benefits by simply pretending to do so. The Italian government had an incentive to tone down as much as possible any expansionary orientation of the budget in order to limit adverse financial market reactions. In fact, the spreads on ten-year Italian government bonds vis-à-vis German bunds increased to around 150 basis points in early 2009, before gradually falling below 100 points already in the Summer (Figure 6). On the other hand, EU countries with worse fiscal starting positions were putting pressure on Germany to act, thus providing the German government with a political incentive to put as much emphasis as possible on the expansionary measures that it issued.

Concerning the composition of the discretionary measures (Figure 7), there are important differences between the two countries. First, while German measures are essentially all deficit-increasing, those adopted in Italy include also deficit-reducing interventions. The financing side of the Italian stimulus measures is essentially based on two capital taxes, both due on a voluntary basis: ${ }^{24}$ a substitute tax on asset revaluations and (for the part of its receipts which was not shifted to 2010) a tax on assets held abroad illegally. While the recourse to these taxes, compared to more standard revenue increases, has limited the negative impact on the consumption and investment decisions of private agents, enhancing the overall stimulus of the fiscal package (see Section 4, below), it will have large costs in 2010 and the following years. The substitute tax on asset revaluations will cumulatively reduce revenue in the decade $2010-19$ by 0.9 per cent of 2009 GDP, approximately twice as much as the receipts obtained last year. Second, the role of tax reliefs is much more important in the German stimulus packages than in those of Italy. As regards expenditure, the measures taken by Germany are only slightly larger ( 0.7 per cent of GDP versus 0.44 for Italy).

24. There were also numerous reductions in expenditure or increases in revenue, with a generally negligible impact. 
118 Britta Hamburg, Sandro Momigliano, Bernhard Manzke, Stefano Siviero

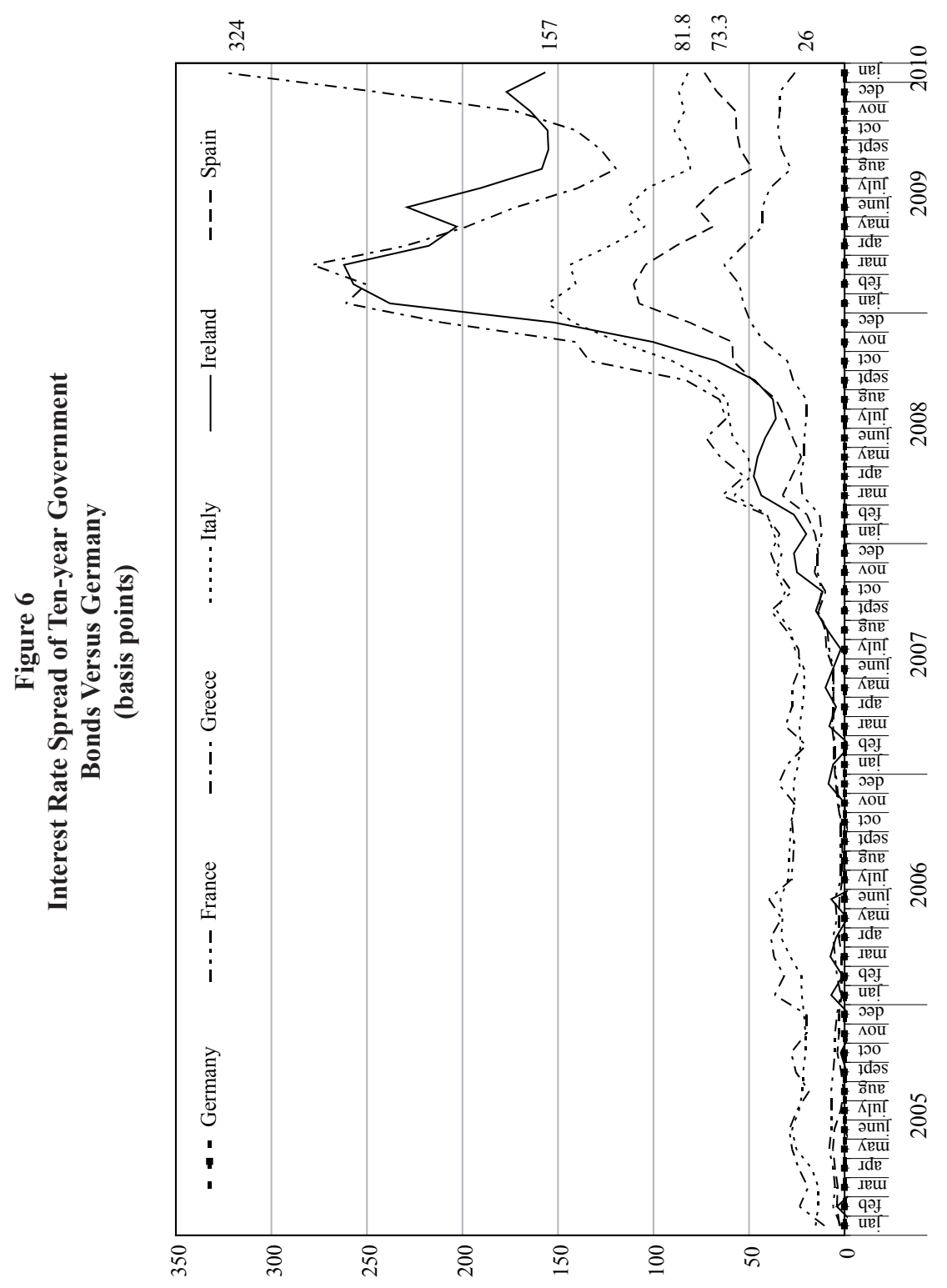


Figure 7

Stimulus Measures in 2009

(percent of GDP)

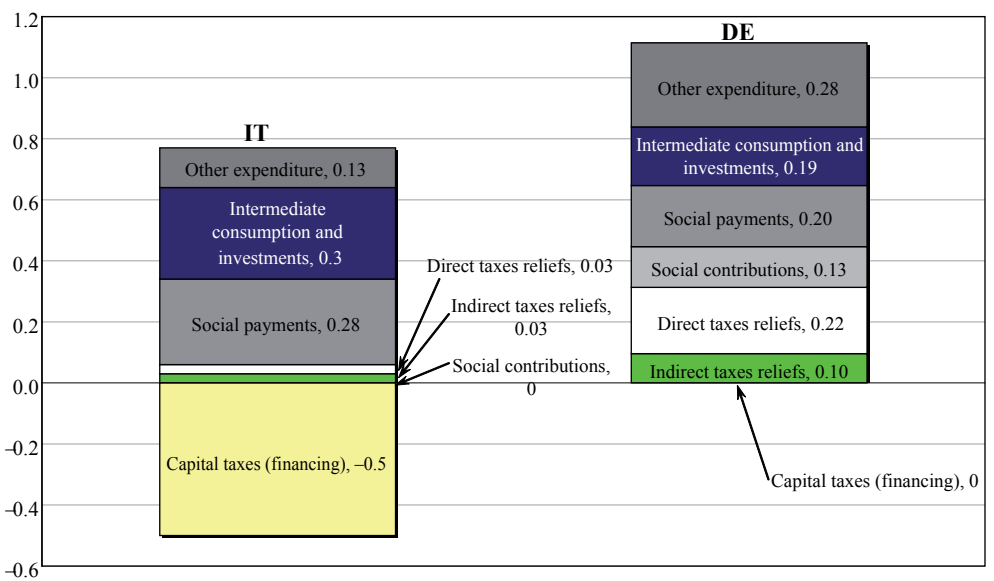

Figure 8

Automatic Stabilizers in 2009

(percent of GDP)

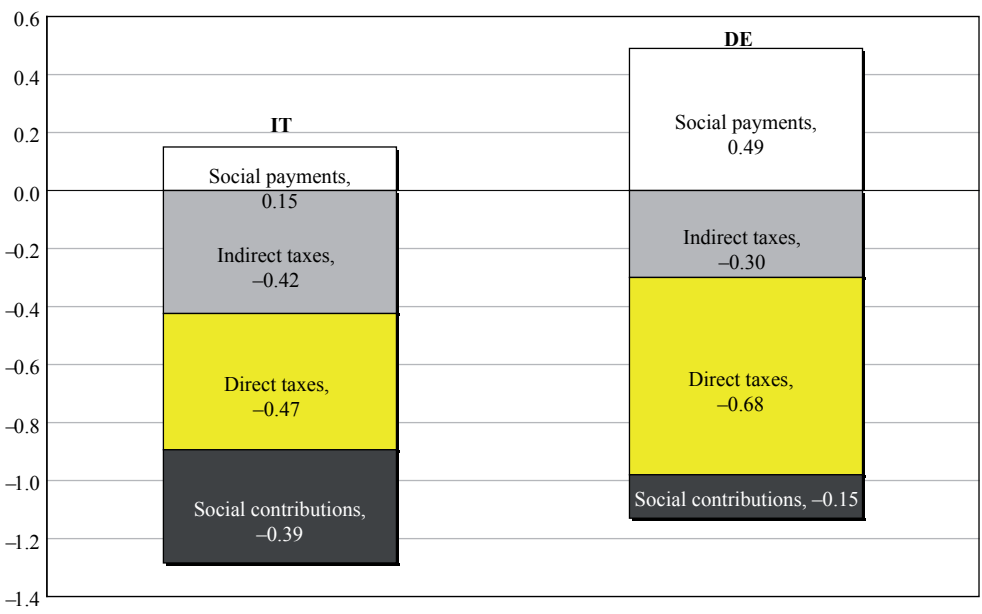

While the size of the automatic stabilizers is comparable in the two countries, the channels through which they operate are somewhat different. In particular, the automatic increase in unemployment-related transfers were much larger in Germany (reflecting its more generous and comprehensive social safety net), while the fall in social security contributions was greater in Italy, reflecting the stronger impact of the crisis on the labour market. 
Going forward, the preliminary picture for 2010 seems more clear cut. While the European Commission in its autumn forecast expects the Italian (primary) deficit ratio to improve marginally, for Germany it is projected to rise by $3 / 4$ percentage points, reflecting further sizeable stimulus measures which are only to a limited extend offset by a positive impact from the cycle. ${ }^{25}$ The deficit reduction projected for the coming years on a no policy change assumption is somewhat stronger for Germany than for Italy. While Germany is projected to reduce its deficit ratio by close to 2 percentage points a $1 \frac{1}{2}$ percentage point reduction is foreseen for Italy. This implies that Italy needs to take additional consolidation measures to comply with the Council recommendation to correct its excessive deficit by 2012 while, without further measures, Germany would reduce its deficit ratio below the 3 per cent threshold by 2011, two years ahead of the 2013 deadline.

\section{Discretionary Measures, AUtOMATiC STABILIZERS, NeUtral BUDGET BENCHMARK, AND THEIR IMPACT ON ECONOMIC ACTIVITY}

To appraise the impact of the budget on economic activity in Germany and Italy for 2009 we use the respective central bank's econometric model (BbkM for Germany and BIQM for Italy $)^{26}$ and compare historical developments against three counterfactual exercises: ${ }^{27,28}$

25. According to the Commission forecast, the positive impact of the cycle on the budget balance/GDP ratio for Germany in 2010 amounts to more than one percentage point. According to the ESCB approach to cyclical adjustment which takes into account the composition of growth (which is unfavourable for public finances in 2010) it is much smaller.

26. For a short presentation of the models used and references to more detailed descriptions, see Appendix 1. For the design of the simulations, see Section 3.

27. Of course, all analyses aiming at appraising the effects of a change in policy are subject to the well-known logical flaw which affects all evaluation of policy measures conducted on the basis of relationships found to hold under a different policy set-up (Lucas, 1976). There are, however, several reasons to believe that in practice the Lucas Critique may be less disruptive than one could think: (i) the behaviour of economic agents may be backward-looking rather than forward-looking; this may be tested empirically (Hendry, 1988; Favero and Hendry, 1992); (ii) even if the agents' expectation formation process is assumed to be forward-looking, the possibility exists that, because of the indeterminacy of the equilibrium, one may still specify rational and "Lucas-proof" decisional rules (Farmer, 1991); (iii) the institutional changes or policy measures in question may not be the "regime shifts" necessary for the Lucas Critique to apply (Sims, 1982); this remark arguably applies to the case at hand; (iv) even if each individual agent were to modify her/ his decisional rule as a consequence of a policy regime shift, the aggregation of heterogeneous reactions may result in an aggregate response that is much less pronounced than each of the underlying individual reactions, so that the actual, aggregate macroeconomic effects of a policy change may be better approximated by an approach that disregards the inherent non-structurality (Altissimo, Siviero and Terlizzese, 2002).

28. As is normally the case, all residuals and add-factors underlying the baseline simulation ("history") were used in all counterfactual simulations as well. A description of the ceteris paribus assumptions underlying all simulations is given in Appendix 3 . 
1) a simulation in which discretionary fiscal stimulus measures are removed; compared to history, this simulation provides an estimate of the impact of discretionary interventions in response to the crisis;

2) a simulation in which, in addition to fiscal stimulus measures, cyclical effects are removed too; comparing this simulation with the previous one we get an estimate of the impact of the automatic stabilizers; moreover, it allows us to appraise the effectiveness and, in a way, the short-term cost-efficiency of the policies which were actively pursued, against those associated with the automatic stabilizers.

3) finally, a simulation in which all items of the general government budget (excluding interest payments) remain at the same level as in 2008, in relation to trend GDP. Further details on the design of this simulation are reported in Appendix 2. The results of this simulation provide a "neutral" benchmark providing an indication of what might have happened in an economy with a fully sterilized public sector.

All possible care was exercised to guarantee that the simulation design was exactly the same for both countries. However, the possibility cannot be ruled out that the differences between the two national models reflect not only genuine differences in the respective country's characteristics - reflected in the models' different parameter values - but also, at least in part, different modeling strategies underlying the construction of those models, despite the broad similarities in their general features (see Appendix 1).

Also, while the fiscal multipliers appear to be much higher in the model for Germany (consistent with previous literature), ${ }^{29}$ there are reasons to believe that, in the case of the specific episode we explore, the actual multipliers associated to changes in the public budget may have been different than in the (average) historical experience. On the one hand, in this exceptionally severe recession, increases in disposable income due to fiscal measures might have resulted in larger-than-usual increases in precautionary savings. Moreover, a more Ricardian reaction than in the past could be induced by higher (expected) debt ratios and fiscal risks from financial sector support (IMF, 2009) and by wealth losses suffered during the crisis. On the other hand, a less pronounced deterioration in public finances would have arguably implied lower interest risk premia (most plausibly in the case of Italy), and therefore higher multipliers, than estimated in our simulations, in

29. The average multiplier for Italy (i.e., the weighted average of the multipliers associated to the different budget items) is less than one third, whereas in Germany it exceeds two thirds. 
which interest rate have been kept unchanged (see Appendix 3 for the treatment of interest rates in counterfactual simulations).

Finally, while we do not appraise the cross-country effects of public sector developments, they are likely to have been non-negligible, given the close trade ties between the two countries.

\section{IV.1 The results}

The estimated effects of the fiscal stimuli are reported in Table 2.

Discretionary stimulus measures have resulted in an increase in the deficit to GDP ratio of 0.8 percentage points in Germany, but of only 0.2 point in Italy. This result includes the cost of discretionary measures (see the discussion in Section 3) as well as the retroaction on the budget of their effects on the economy. In terms of impact on economic activity, the gap between the two countries narrows significantly: the boost which German GDP received from fiscal stimulus measures ${ }^{30}$ in 2009 is estimated to amount to 0.8 percentage points; in Italy it is three quarters that figure ( 0.6 points). This result reflects the large recourse to extraordinary taxes in Italy to finance the stimulus measures. In the BIQM, capital taxation (where these extraordinary taxes are classified) does not directly influence disposable income and has negligible effects on economic activity. It may be argued that this feature of the model is particularly justified in this case, given that the voluntary character of the payments made by the private agents should have strongly limited the negative impact of the tax on their consumption and investment decisions. As mentioned in Section 3, the more effective fiscal stimulus in Italy will have significant budgetary costs in 2010 and in the following years. Excluding capital taxes from net borrowing, the relative effectiveness of fiscal policies of the two countries (in terms of GDP gain for a given increase in deficit) reverses, becoming slightly larger for Germany, reflecting the already mentioned higher fiscal multipliers in the German model. ${ }^{31}$

30. Table 3 reports the effects of all discretionary fiscal measures along with those stemming only for strictly crisis-related measures for Germany; it further presents the sole impact of the carscrapping scheme.

31. This is consistent with the evidence presented in Henry, Hernández de Cos and Momigliano (2008), where, for the first year after the shock, the fiscal multiplier systematically tends to be higher for Germany than for Italy. This is not so, however, for the following year. See also Fagan and Morgan (2005). 
Table 2

Impact of Public Finances on the German and Italian Macroeconomies, 2009

\begin{tabular}{|c|c|c|c|c|c|}
\hline & \multicolumn{2}{|c|}{ Baseline $^{(1)}$} & \multirow{2}{*}{ 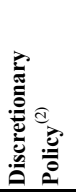 } & \multirow{2}{*}{ 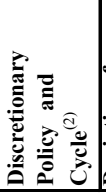 } & \multirow{2}{*}{ 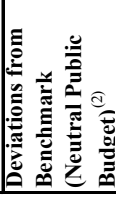 } \\
\hline & $\stackrel{\infty}{\stackrel{\sim}{\sim}}$ & 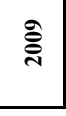 & & & \\
\hline \multicolumn{6}{|l|}{ GERMANY } \\
\hline$\overline{\text { GDP }}$ & 0,7 & $-4,7$ & 0,8 & 2,1 & 2,1 \\
\hline Private consumption & 0,6 & $-0,1$ & 1,6 & 4,2 & 3,5 \\
\hline Total fixed investment & 1,8 & $-10,1$ & 1,7 & 2,6 & 2,1 \\
\hline Exports & 2,0 & $-14,2$ & $-0,1$ & $-0,5$ & $-0,3$ \\
\hline Imports & 2,9 & $-9,4$ & 1,1 & 2,0 & 1,6 \\
\hline GDP deflator & 1,0 & 1,4 & $-0,1$ & $-0,4$ & $-0,6$ \\
\hline Public expenditures net of interest payments & 2,7 & 5,7 & 1,2 & 1,9 & 2,3 \\
\hline Public receipts net of interest receipts & 2,1 & $-2,0$ & $-0,6$ & $-2,8$ & $-4,3$ \\
\hline Public deficit / GDP $(*)$ & 0,1 & $-3,0$ & 0,8 & 2,1 & 3,3 \\
\hline Public deficit net of interest payments and receipts / GDP $(*)$ & 2,5 & $-0,7$ & 0,8 & 2,1 & 3,2 \\
\hline Public expenditures net of interest payments / GDP $(*)$ & 41,1 & 44,9 & 0,2 & 0,1 & 0,4 \\
\hline Public receipts net of interest receipts / GDP $(*)$ & 43,5 & 44,2 & $-0,6$ & $-2,0$ & $-2,8$ \\
\hline Public deficit net of interest payments and receipts / Trend GDP $(*)$ & 2,5 & $-0,7$ & 0,8 & 2,0 & 3,1 \\
\hline \multicolumn{6}{|l|}{ ITALY } \\
\hline$\overline{\text { GDP }}$ & $-1,3$ & $-5,0$ & 0,6 & 1,0 & 1,0 \\
\hline Private consumption & $-0,4$ & $-1,2$ & 0,5 & 1,1 & 1,0 \\
\hline Total fixed investment & $-4,0$ & $-12,1$ & 1,3 & 1,4 & 0,7 \\
\hline Exports & $-3,9$ & $-19,1$ & 0,0 & 0,3 & 0,4 \\
\hline Imports & $-4,3$ & $-14,5$ & 0,9 & 1,4 & 1,2 \\
\hline GDP deflator & 2,8 & 2,1 & 0,0 & $-0,6$ & $-1,6$ \\
\hline Public expenditures net of interest payments & 3,4 & 4,9 & 1,5 & 1,6 & 2,7 \\
\hline Public receipts net of interest receipts & 1,1 & $-1,9$ & 1,0 & $-1,5$ & $-4,5$ \\
\hline Public deficit / GDP $(*)$ & 2,7 & 5,3 & 0,2 & 1,5 & 3,5 \\
\hline Public deficit net of interest payments and receipts / GDP $(*)$ & $-2,7$ & 0,4 & 0,2 & 1,5 & 3,4 \\
\hline Public expenditures net of interest payments / GDP $(*)$ & 44,2 & 47,8 & 0,4 & 0,6 & 1,6 \\
\hline Public receipts net of interest receipts / GDP $\left({ }^{*}\right)$ & 46,4 & 46,7 & 0,2 & $-0,9$ & $-1,8$ \\
\hline Public deficit net of interest payments and receipts / Trend GDP $\left(^{*}\right)$ & $-2,2$ & 1,1 & 0,2 & 1,4 & 3,3 \\
\hline
\end{tabular}

(1) Percentage rate of change, except (*): percentage points.

(2) Percentage difference with respect to the baseline in 2009, except $\left(^{*}\right)$ : percentage points difference with respect to the baseline in 2009 . 
Table 3

Breakdown of the Effects of Discretionary Public Finance Measures on the German Macroeconomy, 2009

\begin{tabular}{lccc} 
& $\begin{array}{c}\text { All Measures } \\
\text { (cfr. Table } 4)\end{array}$ & $\begin{array}{c}\text { Of which }: \\
\text { Taken } \\
\text { in Response } \\
\text { to the Crisis }\end{array}$ & $\begin{array}{c}\text { Of which }: \\
\text { Reflecting } \\
\text { Premium }\end{array}$ \\
\hline GDP & 1,0 & 0,8 & 0,2 \\
Private consumption & 1,8 & 1,6 & 0,7 \\
Total fixed investment & 1,6 & 1,7 & 0,3 \\
Exports & $-0,1$ & $-0,1$ & 0,0 \\
Imports & 1,2 & 1,1 & 0,7 \\
GDP deflator & 0,0 & $-0,1$ & 0,0 \\
Public expenditures net of interest payments & 1,9 & 1,2 & 0,3 \\
Public receipts net of interest receipts & $-0,6$ & $-0,6$ & 0,2 \\
Public deficit / GDP $(*)$ & 1,1 & 0,8 & 0,1 \\
Public deficit net of interest payments and receipts / GDP $(*)$ & 1,1 & 0,8 & 0,1 \\
Public expenditures net of interest payments / GDP $(*)$ & 0,5 & 0,2 & 0,0 \\
Public receipts net of interest receipts / GDP $(*)$ & $-0,7$ & $-0,6$ & 0,0 \\
Public deficit net of interest payments and receipts / Trend GDP $(*)$ & 1,1 & 0,8 & 0,1 \\
\hline
\end{tabular}

Note: Deviations from base line in percent, except $\left(^{*}\right)$ : percentage points.

The estimated impact of fiscal measures on GDP includes the effects of car scrapping schemes (in both countries) and incentives to investment on machinery (in Italy only). Car scrapping schemes were introduced in February 2009 in both countries and expired in September and December, respectively. It is estimated that their contribution to GDP growth in 2009 amounted to 0.2 percentage points in both countries. Investment incentives in Italy (the so-called "Tremonti-ter") were introduced in July 2009 and are due to expire next June. We estimate that in 2009 they boosted GDP by slightly more than 0.1 percentage points.

Preliminary estimates for 2010 (based on projections for both public finance aggregates and macroeconomic variables) suggest that the gap between the two countries in terms of support to growth from fiscal stimulus measures will widen this year: the Italian fiscal impact on economic activity will turn broadly neutral while for Germany it will be broadly the same as in 2009. In both countries, a negative impact on GDP growth is estimated to 
stem from the expiration of the car scrapping incentives. In Italy, this will be broadly offset by higher current expenditure (financed, as in 2009, by extraordinary taxation) and by some (positive) lagged effects of the 2009 measures. In the case of Germany, significant expenditure-increasing and revenue-reducing measures have been implemented for 2010.

While the automatic stabilizers had a broadly comparable impact on the budget balance (1.4 per cent of output for Italy and 1.6 per cent for Germany), their estimated effects on GDP are much more pronounced in Germany than in Italy (1.3 and 0.3 percentage points, respectively). This reflects partly their composition (with much higher unemployment-related payments in the case of Germany) and, to a larger extent, the higher fiscal multipliers in the German model. In both countries, however, automatic stabilizers have been relatively less effective than discretionary measures, in terms of GDP gain for a given increase in current deficit.

Overall, discretionary and automatic fiscal responses to the downturn are assessed to have contributed to reducing the impact of the crisis in 2009 by 1.0 percentage points in Italy and by 2.1 in Germany. ${ }^{32}$ The difference between the two countries virtually vanishes if the extreme assumption is made that the two economies react identically to fiscal shocks and hence the same set of standard fiscal multipliers is used for both countries. ${ }^{33}$

The impact on prices of the fiscal responses to the crisis (automatic and discretionary together) has been more pronounced in Italy than in Germany, reflecting the larger fall (due to automatic stabilizers) in social contribution and VAT in the former country (see Section 3).

The deviations which occurred in 2009 of budgetary components from the neutrality assumption (as defined above) led to a 3 percentage points increase of the deficit-to-GDP ratio in both countries (last column of Table 2). In Italy, the difference can be evenly attributed to both receipts and

32. It must be noted that our estimates do not include the impact of some measures taken by both governments whose effects cannot be easily assessed (e.g., measures taken to foster banks' capitalization, to extend guarantees on deposits, etc.). To put our estimates into perspective, it may be useful to refer, for the Italian case only, to the results in Caivano, Rodano and Siviero (2010). They estimate the effects on output of the reaction of monetary policy to the crisis to be approximately the same as the positive boost of fiscal policy as estimated here. Their estimate, however, does not include the impact of non-conventional monetary policies.

33. We used the set of multipliers of the OECD Interlink model for the euro area presented in Dalsgaard et al. (2001): 1.2 for direct spending and -0.5 for taxes. We applied the multiplier for taxes also to transfers. In this analysis, for both countries, the general government reduced the fall in real GDP in 2009 by approximately $1 \frac{1}{2}$ percentage points. 
expenditures, in Germany, mostly to receipts. The corresponding effects on GDP are, for both countries, close to the overall estimated impact of discretionary measures and automatic stabilizers (previous column of Table 2), notwithstanding the much larger change induced on the deficit.

\section{Concluding Remarks}

The worldwide recession that spread in the fall of 2008 was counteracted by an extraordinarily massive and prompt response of both monetary and fiscal policy authorities everywhere.

In the European context, the recourse to discretionary fiscal stimulus measures and the intensity with which automatic stabilisers operated varied across countries, largely reflecting the different room for manoeuvre set by their different starting conditions.

Germany and Italy, the countries object of this study, responded to the crisis with a relatively ample fiscal reaction by the first and with a limited stimulus by the latter.

Concerning discretionary and automatic budgetary responses, our findings - which overall suggest that differences may be less pronounced than they look - may be summarised as follows:

1) The discretionary stimulus measures in Germany have been markedly more deficit-expanding than in Italy. However, the cyclicallyadjusted primary balances worsened by a similar amount in the two countries; in other terms, the difference in discretionary policies largely offset the divergence in underlying trends (which implied a larger worsening of the budget balance in Italy);

2) contrary to Germany, Italy financed its stimulus measures partly with deficit-reducing interventions characterized by a limited negative impact on the economic activity, with the aim of stimulating the economy while at the same time limiting the short-term effects on the deficit; this policy implies, however, future budgetary costs.

3) the automatic stabilisers are estimated to have had a comparable impact on the deficit of the two countries.

We also assessed the macroeconomic effects of stimulus measures and the overall stabilizing role of the two public sectors on the basis of counterfactual simulations with the econometric models of the two countries 
developed and maintained at the Deutsche Bundesbank and Banca d'Italia, respectively. Our main results are the following:

i) discretionary stimulus measures raised GDP by 0.8 percentage points in Germany and 0.6 points in Italy. For a given impact on the deficit, the effect on Italian GDP is larger, reflecting the differences in the composition of the two stimulus packages (which more than offset the lower fiscal multipliers implicit in Banca d'Italia's model);

ii) by contrast, automatic stabilisers are estimated to have boosted output more in Germany than in Italy;

iii) overall, the general government reduced the fall in real GDP in 2009 by more than 2 percentage points in Germany and by 1 in Italy.

As already noted, the results of our simulations are influenced by differences in the two econometric models, which (though consistent with previous findings in the literature) may or may not fully correspond to genuine differences between the two economies. Under the extreme assumption that the two economies react identically to fiscal shocks, the differences in the combined impact of discretionary fiscal measures and automatic stabilizers in 2009 almost vanish.

\section{Appendix 1:}

\section{THE MODELS USED FOR THE COUNTERFACTUAL SIMULATIONS}

Bundesbank's BbkM: The long-run properties of the quarterly macroeconometric model of the Bundesbank can be described as neoclassical; in the short-run, by contrast, the model features are basically Keynesian. Potential GDP is derived by a Cobb-Douglas production technology with constant returns to scale and long-run growth is driven by variations in population and productivity. Firms and households optimise their behaviour. Their expectation formation process is largely backward-looking (adaptive expectations). The short-run properties of the model are determined by price and wage rigidities. The rather slow adjustment of prices and wages to their equilibrium levels leads to persistent market disequilibria and cyclical fluctuations around the path of potential GDP. ${ }^{34}$

34. A more comprehensive description of the model can be found in Hamburg and Tödter (2005). Since 2005 the model has been used in a version adjusted to requirements of the projection process within the ESCB. Calculations are undertaken with the model focusing on the German economy, where "external" variables (e.g., interest rates, exchange rates, international commodity prices) are exogenous. 
Banca d'Italia's BIQM: The new version of the BIQM shares many of the characteristics of the previous one, released in 1986 (see Banca d'Italia, 1986). Its long-term properties are consistent with a neoclassical model postulating exogenous growth, in which full employment of factors is accompanied by a constant rate of inflation, hence constant relative prices. The levels of output and of the employment of capital and labour are consistent with the parameters of the aggregate production function and with relative factor costs. The steady-state growth path of the model, stemming from technical progress and the accumulation of real and financial wealth, interacts with the dynamics of the adjustment process to determine shortterm characteristics. ${ }^{35}$ The adjustment processes essentially reflect three factors: the stickiness of prices and wages, which prevents their instantaneous adaptation to the situation of full resource utilisation; the non-malleability of installed physical capital, which limits the short-term modifiability of the relative composition of productive factors; and the possibility that expectations and outcomes may not coincide. In the short run, therefore, given these rigidities, the characteristics of the model fit the Keynesian framework in which the level of output is determined by the trend in aggregate demand, in a situation of oversupply in both the goods and the labour market. ${ }^{36}$

\section{Appendix 2: \\ THE DESIGN OF THE NEUTRAL BENCHMARK COUNTERFACTUAL SIMULATION}

To simulate the effects of neutral public budget, we adopt the following definition: the activity of the public sector is deemed neutral if all the items of the general government budget in 2009 (excluding interest payments) remain at the same level of 2008, in relation to trend GDP. ${ }^{37}$

This definition of neutrality includes a small but relevant variant with respect to the definition adopted in previous studies. Specifically, instead of keeping budget items unchanged with respect to GDP, in this case we chose

35. The coexistence of a neoclassical macroeconomic equilibrium framework with Keynesian short-to-medium-term adjustment processes is a feature shared by most existing macroeconometric models (see, e.g., Church, Sault, Sgherri and Wallis, 2000).

36. For a more detailed description of the main properties of the model, see Busetti, Locarno and Monteforte (2005).

37. For a more detailed discussion of the motivations behind this choice, including a critical appraisal of the drawbacks that alternative definitions (e.g., keeping budget items unchanged in real terms) entail, see, e.g., Momigliano and Siviero (1997), where references to the relevant literature may also be found. 
to keep them constant with respect to trend GDP. This choice is justified by the large output drop recorded in 2009 in both countries. Had we kept the ratios unchanged with respect to (headline) GDP, this would have implied slashing all budget items by a very sizeable, and implausible, amount (about 4 per cent in nominal terms). Such a dramatic cut to all budget items could hardly be deemed "neutral". Keeping items unchanged with respect to trend GDP guarantees medium-term neutrality, avoiding excessive fluctuations in budgetary items.

A different criterion was adopted for interest payments, kept endogenous as a function of interest rates and the size of public debt. ${ }^{38}$ Consequently, the counterfactual simulation reflects, via the channel of interest payments, the indirect effects stemming from the counterfactual developments in all other budget items.

It should be emphasized that the "neutral budget" simulation cannot be directly compared with the other two (i.e., with the "no discretionary measures" and "no cyclical effects" simulations), as it ignores by construction any additional information on the effectiveness of specific fiscal policy measures. For instance, the macroeconomic effects of incentives for car purchases (estimated to have boosted the GDP of both countries by 0.2 points in 2009) are included in the previous two simulations, but not in the "neutral budget" one.

\section{Appendix 3:}

\section{TreatMent OF CETERIS PARIBUS ASSUMPTIONS}

This appendix describes the assumptions which were formulated for exchange rates, interest rates and the mechanisms involved in the formation of expectations in all counterfactual simulations.

As regards interest rates, the choice was made to keep the nominal short-term interest rates unchanged with respect to history. Let us remark, in this respect, that our counterfactual simulations, while resulting in a further worsening of the economic activity, do not radically change the picture: the order of magnitude of the recession, though sensibly reduced, remains very large in a historical perspective. It is thus reasonable to assume that monetary policy would not have been much different for our fiscal policy simulations. Let us also emphasize that margins for further expansionary monetary 
policy with traditional tools were limited, given the low levels reached by policy interest rates. ${ }^{39}$ Long-term rates were also kept unchanged.

As regards the (nominal) exchange rate, the technically simple hypothesis of unchanged historical values was adopted; this choice is justified by the same line of reasoning as above.

Instead of the foregoing hypotheses it would have been possible, in theory, to try and take account of the effects of the public finances on the risk premia associated with the issuer and expectations concerning inflation and the exchange rate. Overall, we feel that our choices minimize the margin of discretion and are less arbitrary than alternatives, given the well-known difficulties of finding sensible and empirically robust explanations of risk premia dynamics.

As regards the treatment of economic agents' expectations, the latter are by and large assumed to be of the adaptive type in both models, with the exception of inflation expectations in the BIQM, which are generated by an equation modeling expectations data taken from the Isco-Mondo Economico survey.

It should be noted, however, that some phenomena that may have played an important role in determining the macroeconomic effects of fiscal policy in the case at hand cannot be taken into account. This is the case, for instance, of the public guarantees which were announced, at the peak of the financial crisis, to reassure economic agents (in particular depositors) and hence avoid a meltdown of the financial system.

\section{REFERENCES}

Alesina, A. and S. Ardagna (1998), "Tales of Fiscal Adjustment", Economic Policy, Vol. 13, No. 27, pp. 487-545.

Alesina, A. and R. Perotti (1995), "Fiscal Expansions and Fiscal Adjustments in OECD Countries", NBER, Working Paper, No. 5214.

Alesina, A. and R. Perotti (1996), "Fiscal Adjustment in the OECD Countries: Composition and Macroeconomic Effects", NBER, Working Paper, No. 5730.

39. A possible alternative, though not straightforward, would have been adopting a Taylor rule. At any rate, the changes in inflation and the output gap which result from our counterfactual simulations are overall quite limited and moreover tend to offset one another. 
Altissimo, F., S. Siviero and D. Terlizzese (2002), "How Deep are the Deep Parameters?", Annales d'Economie et de Statistique, No. 67/68, pp. 207-26.

Balassone, F., D. Franco, S. Momigliano and D. Monacelli (2002), "Italy: Fiscal Consolidation and Its Legacy", in Banca d'Italia, The Impact of Fiscal Policy, papers presented at the Workshop organized by the Banca d'Italia in Perugia, 21-23 March.

Banca d'Italia (1999), Indicators of Structural Budget Balances, papers presented at the Workshop organized by the Banca d'Italia in Perugia, 26-28 November.

Bouthevillain, C., P. Cour-Thimann, G. Van den Dool, P.H. De Cos, G. Langenus, M. Mohr, S. Momigliano and M. Tujula (2001), “Cyclicallyadjusted Budget Balance: An Alternative Approach”, ECB, Working Paper, No. 77.

Braz, C.R. (2006), "The Calculation of Cyclically-adjusted Balances at Banco de Portugal: An Update", Economic Bulletin, Vol. 12, No. 4, Banco de Portugal.

Busetti, F., A. Locarno and L. Monteforte (2005), "The Bank of Italy's Quarterly Model”, in Fagan and Morgan (2005).

Caivano, M., L. Rodano and S. Siviero (2010), "La trasmissione della crisi all'economia italiana. Un'indagine controfattuale, 2007-2010”, Banca d'Italia, mimeo.

Church, K.B., J.E. Sault, S. Sgherri and K.F. Wallis (2000), “Comparative Properties of Models of the UK Economy", National Institute Economic Review, No. 171, January.

Corriere della Sera (1998), "Italia nella moneta unica con sei impegni”, 22 March.

Dalsgaard, T., C. André and P. Richardson (2001), "Standard Shocks in the OECD Interlink Model”, OECD, Economic Department, Working Paper, No. 306, OECD Publishing.

De Castro, F., J. Kremer and T. Warmedinger (2010), "How to Measure a Fiscal Stimulus?”, Presupuesto y Gasto Público, No. 59, pp. 103-16.

Degni, M., N. Emiliani, F. Gastaldi, G. Salvemini and C. Virno (2001), "Il riequilibrio della finanza pubblica negli anni Novanta”, Studi e Note di Economia, Quaderni, No. 7. 
European Commission (2009), "Public Finances in EMU 2009", European Economy, No. 5/2009.

Fagan, G. and J. Morgan (eds.) (2005), Econometric Models of the Euroarea Central Banks, Edward Elgar, Cheltenham (UK).

Farmer, R.E. (1991), "The Lucas Critique, Policy Invariance and Multiple Equilibria", Review of Economic Studies, pp. 321-32.

Favero, C.A. and D.F. Hendry (1992), "Testing the Lucas Critique: A Review", Econometric Reviews, Vol. 11, No. 3, pp. 265-306.

Forni, L. and S. Momigliano (2004), "Cyclical Sensitivity of Fiscal Policies Based on Real-time Data", Applied Economics Quarterly, Vol. 50, No. 3, pp. 299-326.

Franco, D. (2002), "Italy: A Never-ending Pension Reform", in M. Feldstein and H. Siebert (eds.), Coping with the Pension Crisis - Where Does Europe Stand?, Chicago, Chicago University Press.

Franco, D. and P. Rizza (2008), "Ensuring a Sustainable Fiscal Consolidation”, in Italy in EMU: The Challenges of Adjustment and Growth, Palgrave, forthcoming.

Hamburg, B. and K.H. Tödter (2005): "The Macroeconometric Multicountry Model of the Deutsche Bundesbank", in Fagan and Morgan (2005), pp. 119-36.

Hendry, D.F. (1988), "Testing Feedback vs. Feedforward Econometric Formulations", Oxford Economic Papers, pp. 132-49.

Henry, J.,P.Hernández de Cos and S. Momigliano(2008), “The Short-term Impact of Government Budgets on Prices: Evidence from Macroeconometric Models", Journal of Policy Modeling, Vol. 30, No. 1, pp. 123-43.

IMF (2009), World Economic Outlook - Prospects and Policies.

Kremer, J., C.R. Braz, T. Brosens, G. Langenus, S. Momigliano and M. Spolander (2006a), "A Disaggregated Framework for the Analysis of Structural Developments in Public Finances", ECB, Working Paper, No. 579.

Kremer, J., C.R. Braz, T. Brosens, G. Langenus, S. Momigliano and M. Spolander (2006b), "A Disaggregated Framework for the Analysis of Structural Developments in Public Finances", in Banca d'Italia (2007), Fiscal Indicators, papers presented to the Workshop organized by the Banca d'Italia in Perugia on 30 March-1 April. 
Kremer, J. and K. Wendorff (2004), "Germany After the Qualification for EMU: A Disaggregated Approach to the Analysis of Structural Public Finance Developments", in Vierteljahreshefte zur Wirtschaftsforschung, Vol. 73, No. 3, pp. 358-70.

Lucas, R.E. (1976), "Econometric Policy Evaluation: A Critique", in K. Brunner and A. Meltzer (eds.), The Phillips Curve and Labor Market, Amsterdam, North-Holland.

Marino, M.R., S. Momigliano and P. Rizza (2008a), “A Structural Analysis of Italy's Fiscal Policies After Joining the European Monetary Union: Are We Learning From Our Past?", Public Finance and Management, Vol. 8, No. 3, pp. 451-501.

Marino, M.R., S. Momigliano and P. Rizza (2008b), "I conti pubblici nel decennio 1998-2007: fattori temporanei, tendenze di medio periodo, misure discrezionali", Banca d'Italia, Occasional Papers, No. 15.

Mc Dermott, C. and R. Westcott (1996), "An Empirical Analysis of Fiscal Adjustments”, IMF, Staff Paper, Vol. 43, No. 4, pp. 725-53.

Momigliano, S. and P. Rizza (2007), “Temporary Measures in Italy: Buying or Losing Time?", in Temporary Measures and Off-budget Activities, Magyar Nemzeti Bank.

Momigliano, S. and S. Siviero (1997), "The Public Budget and Economic Activity in the 1990's: An Analysis with the Bank of Italy Quarterly Econometric Model", Politica Economica, No. 4.

Momigliano, S. and A. Staderini (1999), "A New Method of Assessing the Structural Budget Balance: Results for the Years 1995-2000", in Banca d'Italia, Indicators of Structural Budget Balances, papers presented to the Workshop organized by the Banca d'Italia in Perugia on 26-28 November 1998, Rome, pp. 119-58.

Prammer, D. (2004), "Expansionary Fiscal Consolidations? An Appraisal of the Literature on Non-Keynesian Effects of Fiscal Policy and a Case Study for Austria", Monetary Policy and the Economy, No. 3, pp. 35-52.

Reinhart C.M. and K.S. Rogoff (2009), "Growth in a Time of Debt", mimeo, prepared for the American Economic Review Papers and Proceedings.

Sims, C. (1982), "Policy Analysis with Econometric Models", Brookings Papers on Economic Activity, pp. 106-52. 